\title{
Federal India and Turkish Nation- state: Democracies with a Difference
}

Arshi Khan *

\begin{abstract}
It is generally believed that the systems of governance in most of the countries are inspired by the notion of nation-state for long-term benefits within as well as outside their jurisdiction. What has challenged the notional supremacy of a nation-state is the democratic ethos of governance in multicultural and plural nation-states where democracy, federalism, human rights, rights of minorities, fundamental rights and freedom of expression transformed political landscape.

It is interesting to note that the two democracies-India and Turkey belong to Asia while the latter has also been European territorially with eight land borders and four to five sea borders with European, Asian and Caucasian countries. Turkey lies between the East and the West and between the North and the South. Historically, Turkey is known to possess the rich cultural heritage while India has always been the gate-way to Asia. Moreover, the cultural connotation of Turkey speaks of the 'cohabitation' of two cultures' belonging to two different civilizations.

The creation of Turkish Republic by the Kemalist Revolution was based on the rejection of the history of the people as it happened in case of France. On the contrary, Indian national movement carried over the heritage of various ages including the institutions created by the British rulers. However, in the case of Turkey, the state came with a new project of nation-state, modernity and military elite-guided polity. The Turkish ruling elite headed by Ataturk wanted to act as Plato's Philosopher-King and his army as Platonic system for adequate defense.
\end{abstract}

\section{Keywords}

Federalism, nation-state, Turkish politics, Indian politics, democratization, Jammu and Kashmir, Kurdish issue

\footnotetext{
* Arshi Khan, PhD, is an associate professor in Aligarh Muslim University, Aligarh, India.
} 


\section{Setting the Agenda}

For centuries, particularly since 500 B.C., philosophy of the Greek thinkers, Socrates and Plato onwards, is generally considered by the Western scholars as a decisive turn in the history of human kind for rational generalization and systematic study of political aspects of human beings. Plato's Republic generally referred as the Ideal State is both a moral-ethical institution as well as the reflection of a rational thought particularly in the context of the basic purpose of the formation and continuation of the State system. His 'parallelism' between the 'Individual' and the 'State', is mainly based on the kind of relationship between them not as a 'giver and taker', or 'governor' and 'governed' or a hostile camp of factions but as partners, stakeholders and necessary 'good' for one another.

Meaningful dialogues of Plato in the Republic basically educate us about the main purpose of the state and society particularly in terms of their actions and objectives. In other words, the purpose of political management is to benefit all individuals and groups. This is based on the understanding that every social unit and political institutions are reciprocal, cooperative, friendly and beneficial for one another. In the eyes of Plato, the wealth of a ruler is neither is his/her material possession nor empowerment is his/her desire but selfless service to the people for their well-being. This is the purpose of human wisdom to elevate above the self. Thus it can be understood that the purpose of the state is the well-being of people.

Plato's Ideal State is mostly indicative and suggestive of the fact of pragmatism, legitimacy and civilizational legacy which expect both the people and the ruling institution to promote better opportunities and grounds for unity, harmony, security, justice and peace within the state. This is not an anecdote but the evidence of 
the efforts of the humanity at large in different parts of the world to pursue this agenda on the part of the state. Almost all kinds of states existing today and in the past, all the constitutions and governing philosophies as well as the all the governing institutions in different societies have unanimously claimed for the objective of unity, justice, security, development and peace in the interest of the people. Ionians and Sophists and Greek City-States had made such claims. Similarly the Roman Empire, the Tutonic tribes, Medieval Europe, Renaissance, age of absolute monarchy, political revolutions in America, France, Russia and Turkey and post-1945 Western democracies, including other political formations in different parts of the world have made such claims for national unity, peace and security. However, all such claims can be tested and investigated on the dialectical advance and performance.

On the other hand, it is not very difficult to find out that the zone of conflict, hostility, injustice and disharmony have become almost permanent menace at local, national, regional and international levels. Institutions and processes of close collaborations between the individuals (citizens) and states (authority) created over centuries have either failed to generate 'parallelism' between them or has been set aside for other considerations. As a result, the problem of disharmony, injustice, insecurity, corruption, greed for power and wealth, exploitation, exclusion, conflicts, wars and military occupations are some of the symptoms manifested all over.

As a result, elections have become as a tool of majoritariansim counting 'numbers'. Party based or unelected governments seem to appear more like the rule of the party or personality rather than being the agency for constitutional compliance. Similarly oppositions have become the agency of segmented interests than the voice of the minority. In other words, democratic institutionalism, liberal democracies and others have 
succeeded in creating a territorial, legal, institutional and sovereign state like sprawling metropolitan zones as national and global capitals in which next-door neighbours are no more than strangers. It lacks the features of a community, social club and a commonwealth. It is in this context the role of state and the political community has become extremely important to seek its civilisational goals in the larger interest of humanity. In pursuit of this objective, a reflective attempt is being made examine the cases of two civilisational states which are guided by their own experiences and doctrines to achieve unity, security, justice and peace.

It is interesting to note that the two democracies-India and Turkey belong to Asia while the latter has also been European territorially with eight land borders and four to five sea borders with European, Asian and Caucasian countries. Turkey lies between the East and the West and between the North and the South. Historically, Turkey is known to possess the rich cultural heritage while India has always been the gate-way to Asia. Moreover, the cultural connotation of Turkey speaks of the 'cohabitation' of two cultures' belonging to two different civilizations. It was mainly in Turkey, earlier in the Ottoman Empire, that the East and the West embraced each other. The Ottomans' policy of protecting the interests of different nationalities is exemplary for even most modern federal countries for managing diversities. The history of the Ottoman Empire can be remembered in many ways. Some have taken it as 600 years old hostility to Europe which seems to be a kind of appeasement. In reality, the Ottomans offered opportunities for peace and cohabitation to different nationalities in three continents at sociocultural and economic levels through the Millet system, modernization, and inclusive Constitution of 1876. As a result, minorities were also treated as nationalities which were prospered 
economically and empowered politically. A decree dated $7^{\text {th }}$ May 1572 issued by Sultan Selim II upon the conquest of Cyprus ${ }^{1}$ :

Treat native people with justice and affection. Protect them in court collection of taxes and all kinds of state affairs in order to develop within a short time and to achieve prosperity and happiness. They are entrusted to us by the protector God. It is appropriate to protect and support them for the honour of the state. Let them all live in comfort being sure about their chastity, life and property and concentrate on their economic gains. My justice requires this. Each one of you should be attentive and careful to fulfill this order of mine. Do not show any heedlessness by knowing that I would never accept any excuse whatsoever if I hear you have done otherwise.

In fact, cohabitation existed during the Ottoman era which has gradually turned into duality due to the rejection of the Ottoman legacy in some arenas. Under the Ottomans, varied nationalities survived, protected and prospered due to the governing principles of the Ottoman Empire and the Millet system and till the last days of the Ottoman Empire, non-Ottomans were holding good positions in commerce, banking, industries, press, judiciary, bureaucracy, diplomatic missions, education and army. It was more than the highly echoed term--multiculturalism in which group/national solidarity with the attributes of Will Kymlicka's 'internal restrictions' were given autonomy and freedom in many matters with legal pluralism.

It is also important to mention that the Ottomans continued the practice of socio-legal and cultural pluralism vis-à-

${ }^{1}$ Menter Sahinler, Cyprus Policy 1974 of Turkey (Istanbul: Rumelia Culture and Solidarity Association, 1979), p.103. 
vis other nationalities despite extremely negative trends in the Balkans particularly after the wave of nationalism. National currents sweeping through the Balkan territories had resulted in the ethnic cleansing of the Turks in this area along with the large influx of Muslim (Turk/Ottoman) refugees between 1830s and 1920s. On the other hand, the Ottomans were not taking any retaliatory measures in terms of disturbing their ethnic mosaic. Therefore, social and political foundations of the Ottomans were deeply rooted in justice, peaceful co-existence and tolerance. The Ottomans not only respected 'tolerance' but also practiced it. Thus the Ottoman legacy of over six centuries was a kind of viable alternative to the European Renaissance which gave birth to revolutions, nationalism, dictatorship, colonialism and ethnic cleansing. On the contrary, the French Revolution of 1789 produced 'artillery state' with intolerant (not recognizing minority rights) and militant (adhering to nationalism) citizens.

\section{Artillery State}

The creation of France as the Nation-state was mainly the result of the use of violence by the group opposed to the King Louis XIV which for the first time used about mercenaries to secure victory over the King. On the eve of the French Revolution, nearly a quarter of the French army consisted of foreign soldiers. ${ }^{2}$ The revolutionaries exploited the sentiment of French people by turning the state into a nation and patriotism into national loyalty mainly sacrificing life for the nation. They asked French people to rally their support to them. Soon they made the military service necessary for every citizen. It is in this

2 Menter Sahinler, The Origin, Effect and Currency of Kemalism (Huckelhoven, Germany: Verlag Anadolu GmbH, 1999), p.71. 
context, a violent and militarized citizen of a nation came into being in which Napoleon emerged from among the revolutionaries who used this vast army to conquer the whole of Europe until he approached the outskirt of Moscow in 1812 resulting his defeat in 1815 in Waterloo.

Similarly, the wave of nationalism in the Balkans and other areas were instrumental in creating nation-state but they were mostly intolerant to minorities or other smaller nations. Such trends not only affected the principles of national politics resulting in fascistic tendencies but also resulted in great wars genocidal to the millions which had never happened before. So-called civilisational people and race colonized many parts of the world and their wealth. They became fathers and mothers of divide and rule, bribery and slavery. British and French governments took over Arab territories by mobilising Arabs in the name of Arab Nationalism and damaged the Ottoman Empire by showing friendship. The French armed the Armenians during the First World War against the Ottomans. Thus the colonization of Palestinians and artificial creation of Israel are also rooted in Western colonial and post colonial policies.

It is in this context one can also find the blooming of the concept of modernity emphasizing universalisation of principles along with liberal democracy. The collapsing Ottoman Empire was reconstructed into a Republic mainly consisting of the Rum (Anatolia) by the freedom fighters under the leadership of Ghazi Mustafa Kemal Pasha against the occupying armies of several European powers. Irreparable loss of the Ottomans, their defeat in the Arab world and humiliating features of the Treaty of Sevres of 1920, had turned the Ottoman Empire into Turkish Nation-state based on European life pattern, legal codes, rules, policies and defense. 
The birth of the Republic of Turkey as a Nation-state was mainly the result of the Kamalist Revolution which was one of its own kinds in the series of other revolutions. It was more similar to French than the American Revolution of 1776 (opposed to the domination of the British Paramountcy) and the Russian revolution of 1917 (industrial and anti-Czarist). The Kemalist Revolution (1923-38) was mainly against the existing social, legal and political order. It rejected almost every aspects of the past and rewrote a new history of Turkey. It was setting the agenda of the Turkish nation-state in the premise of the 'civic law' system and with the 'continental approach' to the polity. During the War of Liberation, Kemalists adopted such ideas of the French revolution as independence, national will, and patriotism. ${ }^{3}$

In the French tradition, to which the Turkish stood closest in Ataturk's time, parties have often been suspect as being little more than factions, seeking private advantage and status, mere 'conspiracies against the nation' the same basic instinct that has manifested itself, if less vehemently, in Britain and the United States. The French revolutionaries were too intellectual and too radical to tolerate a muddles British approach of necessary compromises, however. It was they who said that all political parties undermined the sovereignty of the people representing 'general interest', taking inspirations from J. J. Rousseau. The only worthy party is the one which liberated the people. ${ }^{4}$ The Kemalists describe revolutionism as the alteration of present institutions by force, demolititon of the old institutions and the establishment of

${ }^{3}$ C. H. Dodd, "Ataturk and Political Parties", Metin Heper and Jacob M. Landau, eds., Political Parties and Democracy in Turkey (London, New Yoprk: I.B. Tauris \& Co Ltd, 1991), p. 26.

${ }^{4}$ Menter Sahinler, The Origin, Effect and Currency of Kemalism, p. 101. 
new ones according to development and requirements of modern civilization. $^{5}$

The Kemalist Revolution was against the foreign occupation, the Ottomans and democracy. It was highly authoritarian in nature and used all kinds of coercive organs of the state to anti-Kemalist views. Kemal himself was against any opposition to his Republican Peoples Party formed by Kemalist army high officers, established in November 1923. To him, political parties were exclusive in nature and promoted factional interests damaging to the nation and the country. However, the most distinguished aspect of this revolution was setting the internal agenda of stability and peace abroad in comparison of the agenda of the colonial expansion of the Western Europe on the one hand, and the phenomenal rise of fascistic tendencies in Germany and Italy, on the other. Turks were also facing territorial threats from the Western powers which were controlling different territories of West Asia. Greece and the Balkans, former colonies of the Ottomans, were not very friendly neighbours while the Communists on its north were biggest menace to them.

It was in the midst of such strains, the Kemalist Revolution was thought by the ruling elite to be the only way out for the Turks to be a competent member of the European family which resulted in a long drive for a kind of metamorphic transformation. Under the doctrine of nation-state, one nation, one language and one culture became the mother of nationhood and opposing or differential trends were brutally suppressed on the pretext of freedom, democracy, security, peace and development. Such tendencies had started growing after the end of the World War II

${ }^{5}$ P. Harris and B. Reilly, eds., Democracy and Deep-rooted Conflicts: Options for Negotiators, (Stockholm: International IDEA, 1998), pp. 1-10. 
which further grew after the collapse of the Soviet Union in 1990. This is being followed by the dynamics of globalization, market economy, democratic idealism, democratic institutionalism, multiculturalism and human rights.

What has resulted as the most challenging aspect of nationstate is the dominant and indivisible nature of sovereignty. As a result, state and its elite have emerged as the only legitimate heir of the principles of governance, conflict resolution and trend setter in national and international politics. This can be reflected in various hostile camps claiming values for secularism, peace, justice, democracy and unity based on their own narratives. As a result, politics within some states seem to be a kind of 'cold war' between uncompromising factions which have even invited foreign interventions for their own interests. In other words, states seem to appear as a complex of divided and hostile neighbours who see loss in the benefits of the other. Such divisions further influence media, civil society, educational institutions, bureaucracy and other spheres of life not based on cultural differences but of their conflicting interests.

Media, bureaucracy and military elite and the opposition mounted psychological pressures on the Justice and Development Party (AK Party) government of Recep Tayyip Erdogan in early 2007. Politically motivated demonstrations were organized in few places to make the propaganda that Kemalism is under threat of Islamic fundamentalism. Elections dates were declared six months before the completion of the full term of the government. As a result, an AK Party leader Abdullah Gul's democratic contest for the post of the President of Turkey was delayed and ended. However, the AK Party again won the Election in mid 2007 with increase in the percentage of vote in its favour in comparison to the last elections. Finally Gul was elected as the President of Turkey. Chief of the Turkish armed forces and the Republican 
Deputies did not attend the ceremonial function of Gul's ascendancy but the AK Party's acceptability grew at large.

On the other hand, Sarkozy, well known for his antiTurkey and anti-Muslims prejudices, was elected as the French President with full national respect. Whereas Gul is neither racist nor prejudiced against anyone. Such attitudes were quite disturbing trends in Turkish democracy because the armed forces showed extremes of undesirability, intolerance, unnecessary suspicion and over-vigilance. Democracy is basically the peaceful management of conflicting and different interests. It is for unity and collaboration. AK Party's presence in Turkey and its government represent people's mandate as national will. On the other hand, the AK Party never said to disturb country's political order and culture. Unfortunately, oppositions to the AK Party, claiming to be Kemalists, believe in the Kemalism of 1920s and 1930s. Situations in and around Turkey have changed necessitating reforms/changes within Kemalism in order to make it responsive to the people.

Thus the pride in a nation-state became more of a global phenomenon occurring in different parts of the world. Ethnicisation of the Soviet Union by the Russians caused its disintegration and the break-up of the communist Eastern Europe. On the other hand, it has inflamed ethnic tensions and separatist tendencies in many Afro-Asian countries. The affected states are at war with their own nations which have been taken by the West as an opportunity to alter international law on the pretext of 'democratic entitlement' of the people. As a result, ethnic conflicts are emerging setbacks for nation-state (in terms of denying to minority/ethnic group) and for other polities (in terms of token and symbolic accommodation of minority rights in governance and decision making). In other words, both the kinds of polities suffer from inherent deficiencies and institutional-operational 
duality respectively particularly in the domain of constitution making and nation making.

Therefore, the recognition of the role and status of the individual, group and society in the management of the government determine the prospect of unity, peace and harmony. Citizens as stakeholders or valued partners in the affairs of state and society have promoted stability and unity while their status of being merely subjects is counter-productive in nation-building. As the twenty-first century opened, analysts were able to find out that the nature of human conflict had profoundly changed, both in regard to its form and its subject-matter. Whereas the previous century opened with inter-state wars-wars between sovereign states-by the 1990s the overwhelming majority of conflicts classified as "major armed conflicts" were intra-state conflicts. Between 1989 and 1996, for example, 95 of the 101 armed conflicts identified in the world were internal, and the vast majority had an "identity" component to them. ${ }^{6}$

While such conflicts may be triggered by or combine with questions of distribution of economic resources or opportunities, their "identity"-driven nature has allowed them to be characterized as more intense, intractable, emotionally charged, and persistent. ${ }^{7}$ These conflicts arise when a given national political framework no longer holds the loyalty of a rebellious cultural group. The nation is no longer a home for one or more of its subnational communities. Constitutional frameworks, whether inherited or long entrenched, appear incapable of managing the increasing assertiveness of identity politics. At the same time the

${ }^{6}$ Ibid., p.10.; R. Stavenhagen, Ethnic Conflicts and the Nation State, (New York: St Martins' Press, Inc, 1996, p. 229.

${ }^{7}$ P. Harris and B. Reilly, eds., Democracy and Deep-rooted Conflicts: Options for Negotiators, p. 15. 
cost of identity conflict is increasing in both human and economic terms. ${ }^{8}$

Nationalism certainly helped in national freedom struggle in the colonial countries but later it produced strong internal divisive trend resulting into partition due to the fear of minority against the majority. The case of India is an interesting example. It was due to the take-over of the negotiating space by the majoritarian domination (national freedom first) and minority parity (communal/Hindu-Muslim settlement first) which led to the partition of the country in which people from both the sides suffered heavily. Despite the genocidal partition of the British India, neither of the country (India, Pakistan) emerged as nationstate. Both were federal at social and constitutional levels. Pakistan which failed to accommodate Bengali national sentiments was divided in 1971 and other nationalities are not reconciled with the federal government. Similarly, India resorted to various measures at the policy and institutional levels in its federal management but the problems exist in Jammu and Kashmir and North-East. India succeeded in tackling the problem of secessionism in Punjab but many districts (about 175) are infected with Naxal or other kinds of violence.

On the other hand, the problem of caste-based differences and violence exists at all-India level. The second biggest majority group, i.e., the Muslim community stands excluded in various spheres of public life along with over 14000 communal riots so

8 Arshi Khan, "Situating Federalism, Minorities and Communalism in the Indian Polity”, European Yearbook of Minority Issues, 4 (2004/2005), pp. 101 102; Arshi Khan, "Police Prejudice against the Muslims", in Asghar Ali Engineer and A.S. Narang, eds., Minorities and Police in India (New Delhi: Manohar Publishers and Distributors, 2006), pp. 141-162. 
far. ${ }^{9}$ Such problems show the threads of strains between the empowered and excluded sections of society on the one hand, and the problem of relationship between the state and the affected segments, on the other. Thus federal countries also lack willingness to share powers in consociational form. They have produced majoritarianism in place of concurrent majority. As such overarching phenomenon of majoritarianism, majority nation is echoing one nation, one language and one culture which mirror institutional federal state as operational nation-state. It is in this context, brief discussion is made over the major attributes of Indian and Turkish polities.

\section{Understanding Federalism and Federal India}

Before talking Federal India, it would be imperative to mention federalism which has been the principle of governance this continental country. A Federal Nation is not homogeneous like a nation. It is a mosaic of socio-cultural heterogeneity, diversities and pluralities, aggregated into a unified political sovereignty. It has aspects of commonality and uniformities co-existing with aspects of distinct specificities. Its hallmark is unity of polity and plurality of society. ${ }^{10}$ Federalism offers a viable ideology to manage multicultural societies. It is inseparable from democracy and consociationalism. Federal attributes range from decentralization to minority rights. Federalism is basically committed to non-centralization and nonmajoritarianism. It not only prescribes the principle of proportionality but also specially takes care of the interests of

9 Rasheeduddin Khan, Bewildered India: Identity, Pluralism, Discord (New Delhi: Har-Anand Publications, 1995), p. 13.

10 Thomas Fleiner and Lidija R. Basta Fleiner, "Federalism, Federal States and Decentralization", Federalism and Multiethnic States: The Case of Switzerland (Bale, Geneve, Munich: Institut Du Federalisme Fribourg Suisse and Helbing \& Lichtenhahn, 2000), pp. 39-40. 
minorities and other vulnerable groups. Examples are the some countries-Switzerland, Canada, Belgium and Nigeria where nonmajority groups have been provided with adequate constitutional guarantees for their participation and inclusion.

Thomas Fleiner and Lidija R. Basta Fleiner have argued that minority protection has to be understood merely as immanent to a democratic question. If both federalism and democracy, when interpreted as constituting principles, are principles of power control, the main problem can be summed up as follows: Can the equality of all citizens be understood in away that permits also local, i.e. group liberty? They understand federal democracy as a political ideology based on limited democracy which is respectful for both individual and minority rights. This democratic objective can be achieved only by providing for constitutional frameworks which will take into account social differentiation along ethnic, cultural, confessional, linguistic and the like lines that minority can be made an inherent element for constituting a given federal state. With regard to have a proper constitutional basis for the protection of minority rights, minorities are to make an inherent element of legitimizing a given federal order. ${ }^{11}$

Lidija R. Basta Fleiner has rightly said that federalism is an anti-majoritarian device and one of the major checks-and-balances instruments. This is why constitutional setting-instruments of legal control of political power, rule of law, human rights, independent judiciary and the like, are indispensable in order to have federalism work. ${ }^{12}$ It basically conforms to the idea of

${ }^{11}$ Lidija R. Basta Fleiner's views in the Scientific Summary of Sessions 5 and 17 based on Case-Studies of Cyprus, Serbia and Montenegro, South Africa and Switzerland, Conference on Federalism, Federalism in Changing World_Learning From Each Other, St. Gallen, Switzerland, 27-30 August 2002.

12 Ibid. 
multiculturalism which recognizes socio-cultural rights of the individuals belonging to minorities. More like what is more clearly expressed under the UN Charter and Universal Declaration of Human Rights which are strictly based on liberal-contractualist paradigm.

On the contrary, the Ottomans' Millet system was more accommodative for the rights of different groups and communities who exercised maximum autonomy and consequently strong considerations of their influence and safeguards in power structures. But the post-classical liberals have almost avoided being considerate towards group rights under which they fear threat to individual's autonomy and rights. But certainly in many writings, scholars on federalism have made strong impression of their concern for taking the interests of people based on the rejection of exclusion. In the words of Lidija Fleiner, federalism aims at accommodating multicultural pluralism which inevitably builds on vertical power sharing and proportional representation. ${ }^{13}$ Daniel J. Elazar finds federalism as a political force because it serves the principle that there are no simple majorities or minorities but that all majorities are compounded of congeries of groups, and the corollary principle of minority rights, which not only protects the possibility for minorities to preserve themselves but forces majorities to be compound rather than artificially simple. It serves those principles by emphasizing the consensual basis of the polity and the importance of liberty in the constitution and maintenance of democratic republic. ${ }^{14}$

13 Daniel. J. Elazar, Exploring Federalism (Tuscaloosa: The University of Alabama Press, 1987), 2.

${ }_{14}$ Views of Thomas Fleiner, Walter Kalin, Wolf Linder and Cheryl Saunders in the International Conference on Federalism on Federalism in a Changing World_Learning from Each Other, St. Gallen, Switzerland, 27-30 August 2002. 
Scholars recognized the fact that ninety-five percent of the world population lives in multicultural states, fragmented into different cultural communities. Forty percent of these people live in federal states. In their opinion, collective rights are other potential tools for reducing multicultural conflicts. They found majoritarianism, which overrules the vital interests of minorities, as the main cause of ethnic conflicts in multicultural societies. They also raised objections over the legitimacy of a state where majoritarianism has excluded minorities. Therefore, they suggest a pressing need to find institutions, principles and tools that can accommodate diversity. ${ }^{15}$

Thus the objective of federal governance is all about building such a polity and society in which individual and groups, minorities and majority, governments and public trust and cooperate one another despite being critic and competitive. In the contemporary world, they are expressed in one dominant form, i.e., the principle of territoriality. In other words, different layers of governments, commonly known as federal government and constituent units, together legitimize the supremacy of the constitution as well as choice and will of the people and public. Lidija Fleiner has said that democratic integration of multicultural societies remains a major challenge, not only as an objective, but also as a strategy. She has warned that the "winner takes all" system within pluralist and segmented societies inevitably produces illegitimate group politics. There is a great reason in her summation that it is federalised democracy both as a strategy of constitution making, which can critically contribute to nation building in multicultural societies. ${ }^{16}$

15 Views of Lidija R. Basta Fleiner's in the Scientific Summary of Sessions 5 and 17 based on Case-Studies of Cyprus, Serbia and Montenegro, South Africa and Switzerland, Conference on Federalism 2002. 16 Arshi Khan, The Individual and the Groups in the Nation-state, Monograph, Centre for Federal Studies, 2005, pp.1-13. 
Independence of India was not the result of any revolution but of a long movement of freedom struggle which carried over the masses led by western educated elite. This freedom movement was quite parliamentary and peaceful in nature which indicated the participatory role of people in the management of the country. India's social diversities and regional variations are comparatively more than the pluri-national identities of the European Union. Despite facing many challenges in some regions and a porous border with nascent democracies and military administered institutions, India seems to be committed to the path of greater reconciliation, conflict resolution, democratization and empowerment of the people in general.

India has held 15 successful Parliamentary elections with a large number of elections for State Legislative Assemblies. Democratization at the local level seems to be a kind of revolutionary achievement in empowering people in general and women and weaker sections in particular. The emerging local selfgovernments for rural and urban sectors is a massive experiment with democracy, which is resulting in the creation of an assertive 'periphery'. There are three million elected representatives at the periphery. This periphery is on its way forward towards taking a centre-stage in determining the rise and fall of governments at federal and constituents' levels.

The Indian Constitution has been carrying out several projects for the welfare of the people, affirmative action policies for the backward classes, protection of minorities, welfare measures for tribal communities, strengthening of the parliamentary democracy, securing federal arrangements for strengthening the Union/Federal Government, promoting the rights of the States in the Union, certain special rights for some States and for many other integrative objectives at the federal and 
sub-federal levels. There has been one major objective of the Indian Constitution-to secure 'unity' at the territorial and nonterritorial levels. The primacy to 'unity' is the key to enter into a network of political and social arrangements. Indian polity seems to have proved to be the key to seek such a kind of unity in the larger interests of the society, communities, constituents and the Union. Thus Indian political system is so designed that it can address the issues at symmetrical and asymmetrical levels. The greatest achievement of the Constitution is its very survival so far. When several sister constitutions in Asia and elsewhere have either crumbled down or have entered into crises, India has had here peace and progress, order and economic achievements. It is the sixth largest GDP country in the world.

It has partly inspired the new Constitution of South Africa. India's federal attributes are so vast and pervasive that they can also be found in leading federal polities of the world. The Indian Constitution has recognized both universal principles of Fundamental Rights along with considering differential rights for non-majority groups. It created States based on the socio-cultural aspirations of the people in a given territory. But it does not mean that the Constitution is not without defects and danger-spots. K.V. Rao who wrote $A$ Critical Commentary on Parliamentary Democracy in India in 1960, commended the role of the Indian leaders who combined their zeal for unity with the high will of keeping the country united and integrated. He called them 'old guard' of the Congress who 'had the real interests of the country at heart. These old guards almost vanished by 1960. In other words, the process of 'consolidation of the Indian Union' at the bureaucratic and procedural level progressed along with the crystallization of those political institutions through which civilian leadership continued to gain dominance over the decision-making and enforcement of laws. 
Federalism is one of the dominant features within the Constitution without using the word 'federal'. The term 'Union' is preferably used to indicate four things, (a) that the Indian Constitution is not the result of the agreement by the units, (b) that the constituents have no entitlement for secession, (c) that the Union can directly control the units in case of the failure of the constitutional machinery therein, and (d) that the Union is privileged with more powers, influences and incentives than the constituent units. Residuary powers rest with the Union as it is found in Canada. Consultations with the States and their consents are not pre-requisites for bulk of the constitutional amendments by the Federal government. The Governor has the power to reserve a State Bill for the consideration of the President before it becomes Legislation. The President appoints the Governor of a State who shall hold office during the pleasure of the former. They are similar to the Canadian situation but not in the case of the United States and Australia. ${ }^{17}$

\section{The State of Jammu and Kashmir}

Jammu and Kashmir is a State within the Indian Union forming a part of the Indian Territory as specified in the First schedule of the Indian Constitution. JK enjoys special constitutional position under article 370 of the Constitution. The King of JK Maharaja Hari Singh signed the Instrument of Accession with the Indian Union on 26 October 1947 in the event of war with Azad Kashmir Forces. JK became a State in Part B of the state category without any effect provisions of Part B on it. Because the Government of India expected the Kashmiri people to determine their future through their Constituent Assembly. The

17 Arshi Khan, Indian Political System, Monograph, Centre for Federal Studies, 2005, pp. 33-39. 
Constituent Assembly of India adopted JK as a part of the territory of India. Only two Articles-1 and 370 were made to apply to JK and the rest depended upon the determination of the President in consultation with the JK Government. Legislative competence of Indian Parliament over the State was confined toDefence, Foreign Affairs and Communication as items of the Union and Concurrent List. This interim arrangement was to continue till the Constituent Assembly for JK made its decision.

The President of India made a Constitution Order, 1950, in consultation with the JK Government specifying the competencies of Parliament in the domain of the three subjects with reference to the State. In 1952, the Union and the JK Government signed an Agreement in Delhi as to the subjects over, which the Union should have jurisdiction over the State. The Constituent Assembly of JK ratified the Accession to India and the Delhi Agreement in February 1954. In consultation with the State, the President made the Constitution Order, 1954which superseded the 1950 Order. As a result, the Union extended its jurisdiction to all Union Subjects mentioned in the Constitution. This Order was amended in 1963, 1964, 1965, 1966, 1972, 1974, and 1986. JK finally got its Constitution on 26 January 1957, amended till the year 1984. It declares JK an 'integral part' of the Union of India. The Jammu and Kashmir ( $6^{\text {th }}$ Amendment) Act, 1965 withdrew the title Sadar-iRiyasat by accepting the nomenclature of "Governor" and agreed to the constitutional power of the Union to appoint the Governor to JK by the President like in other States. So there is symmetry on this point between JK and other States. It is also found in the working of the JK Assembly, High Court, and Public Service Commission.

There are some vital points of 'difference'. The Union Parliament's jurisdiction extends to the Union List and limited jurisdiction in subjects on the Concurrent List. Residuary powers, 
which rest with the Union in relation to other States, rest with JK Legislature, with the exception of certain matters specified in 1969 in which Parliament would prevail against any threat to sovereignty and integrity of the country. The State has the right to legislate for preventive detention, which belongs to the Union in all other States. Article 249 is now effective vis-à-vis JK after the Constitution Order of 1986. The CAG, Election Commission, and the Special Leave Jurisdiction of the Supreme Court are now extended to JK.

The State's consent is mandatory for the Union in the case of Article 3 and any international treaty affecting JK. Consent of the State is also a condition before the Union for applying Article 352 (imposition of national Emergency on the ground of internal disturbance). Article 360 (Financial Emergency) and Directive Principles of State Policy, under Part IV of the Constitution of India, is not applicable to JK. Article 19 is subject to special restrictions for a period of 25 years. Permanents residents of the State have 'special rights' in relation to employment and property. $\mathrm{JK}$ has the provision for the Governor's Rule (provided by the State Constitution, with the concurrence of the President) and the President's Rule to meet exigencies. Effects of article 365 are restricted. The JK Legislature can amend its State Constitution (except those concerned with the relations with the Union) by two-thirds majority. President's assent is not required. If the Bill affects the Governor or the Election Commission, it is to be reserved for the assent of the President. Any amendment by Parliament is not extendable to JK unless it is driven by the Order of the President under Article 370(1). 


\section{Local Governance}

In 1992, Parliament brought 73 and $74^{\text {th }}$ Amendments to empower people through local institutions of governance and development. This new system was characterized by periodic elections, reservation of seats for Scheduled Castes and Scheduled Tribes on the principle of 'proportionality' and not less than $1 / 3$ of the total number of seats for women. There are also provisions for reserving the seats of the offices of Chairpersons in favour backward classes of citizens. Democratic experiment at the grassroots level envisaged three layers of Panchayats-the Village level, District level Panchayat, and the Intermediate Panchayats where the population is above 2 million. Elections for every Panchayat are held every five years. State Legislatures confer powers on the Panchayats to manage developments, social justice, and implementation of developmental schemes.

There are 29 items such as land improvement, minor irrigation, animal husbandry, fisheries, education, women and child development in the Eleventh Schedule (inserted by $73 \mathrm{rd}$ Amendment for distributing powers between the state Legislature and the Panchayats). The $74^{\text {th }}$ Amendment made the constitutional foundation of local governance in urban areas with many features resembling the Panchayats in the field of safeguards for SCs, STs and women. It created two institutions-for governance and planning. At the governance level, there are three types of 'municipalities'-Nagar Panchayat, Municipal Council, and Municipal Corporation.

The municipalities are constituted through election every five years with the description of their competencies in the Twelfth Schedule of the Constitution of India. It is to confer powers to the municipalities for preparing their developmental plans, implementation of schemes and about their responsibilities 
against 18 subjects in the Twelfth Schedule. It confers fiscal powers to them like it does for the Panchayats. Like the Panchayats, Municipalities are also benefited by the role of the Finance Commission of the State and the State Election Commission. There are also special arrangements for constituting District Planning Committee and the Metropolitan Planning Committee to prepare and forward development plans to the State Government.

There are some special provisions under the Fifth and the Sixth Schedule of the Constitution for the management and governance of Tribal Areas in two category of States. The Fifth Schedule identifies the Scheduled Areas in the States other than Assam, Meghalaya, Tripura and Mizoram, which are inhabited by the Tribes. The President of India is authorized to declare any area as Scheduled Area as it was done by the Scheduled Areas Order, 1950 mainly due to its backwardness. The Sixth Schedule identified the Tribal Areas in the States of Assam, Meghalaya, Tripura and Mizoram. Both the Fifth and Sixth Schedules of the Constitution make special arrangement for the administration in the abovementioned Areas. The Sixth Schedule deals with the administration of Tribal Areas in Assam, Meghalaya, Mizoram and Tripura. The Tribal Area shall be Autonomous District with the right of selfgovernance. The Sixth Schedule possesses important provisions for the creation of District Councils (for Autonomous Districts) and Regional Councils (for Autonomous Regions) armed with certain legislative and judicial functions. ${ }^{18}$

18 "Forward", in A.P.Vijapur, ed., Dimensions of Federal Nation Building (New Delhi: Manak Publications, 1998). 


\section{Constitutional Considerations for Weaker Sections and Minorities}

India accepted federal principles of governance to accommodate social diversities-religious, regional and linguistic. Officially minorities are defined in religious terms. Religious minorities are either area specific or dispersed. India has eight religious communities. Hindus and Muslims are first and second majority communities. Muslims are not only backward in comparison to the Hindus but they are also far behind all six minority communities in the country with the exception of tiny neo-Buddhist community. The Indian Constitution has taken a wide variety of measures to accommodate several demands of such groups and communities, mostly belonging to the Hindu religion and tribal community. It is also important to mention that the federal and federated policies have been not been in favour of any group rights in terms of guaranteeing representation in elected bodies and job reservations. It has ensured constitutional protection for the communities which want to preserve their socio-cultural identity provided such freedoms do not violate the fundamental rights. In this context, it would be imperative to look into the words of the late President of India, K.R. Narayanan ${ }^{19}$ Said:

But, at the same times, we have come to realise that nationhood has different depths of meaning and varying levels. It contains both abstractions as well as particularisms. For every citizen, India means a country as well as a region; a region as well as a neighbourhood and a locality. It means a language as well as a dialect... This bifocal perception of the distant and the near, the general and specific, has made India's nation-building a unique and

${ }_{19}$ Myron Weiner and M. Katzenstein, et al., India's Preferential Policies (Chicago: Chicago University Press, 1981), p. 1. 
fascinating exercise. Given our continental proportions, diversity of race, languages, regions, our history and our past experience in nation-building during the five decades since independence, India could not but have acquired federal features. Unlike most other nation, we are not built around a single race, language or religion. Ours is perhaps a more pluralistic entity than any other nation on earth.

There are special directive for the protection of linguistic rights. Under Article 350, every person is entitled to submit representation for the redress of any grievance to any officer or authority of the Union or a State in any of the languages used in the Union or in the State. Minorities' linguistic rights are safeguarded by Article 350A which recommend every State and of every local authority within the State to provide adequate facilitates for instruction in the mother-tongue at the primary stage of education to children belonging to linguistic minority groups; and the President may issue such directions to any State as he considers necessary or proper for securing the provision of such facilities. Under Article 350B, the President shall appoint a Special Officer for linguistic minorities who will be assigned with the following tasks-to investigate all matters relating to the safeguards provided for linguistic minorities and report to the President upon those matters at such intervals as the President may direct, and the President will send the reports to the each House of Parliament and Governments of the States.

This is to note that the Indian federal government has responded continuously with sets of preferential policies to achieve greater equality among ethnic groups in the shape of laws, regulations, administrative rules, court orders, and other public interventions. These together are known in India as "protective discrimination" in areas such as admission into school, colleges and universities and such other institutions, jobs, promotions, 
business loans, and the right to buy and sell land on the basis of membership in a particular ethnic group. ${ }^{20}$ The affirmative action programme in India consists of two types. Under one set of constitutional provisions, special benefits and exclusive preferences are offered to members of Scheduled Castes and Scheduled Tribes. They are given preferences in admission to educational institutions with special stipends and reservation of seats in employment and promotions in government sector. They are also provided with reserved seats in elected bodies at national, state and local levels (Parliament, State Legislatures, Municipalities, Panchayats and other statutory bodies). The affirmative action programme also includes 'Other Backward Classes' who are predominantly Hindus.

The second set of affirmative action programme is for local ethnic groups in competition for higher status, higher salaried jobs and for lower ranking jobs in institutions at local level where migrants also employed. Residential and domicile rules prefer the local inhabitants in educational institutions. In the formulation of affirmative action policies, state governments generally matter more particularly in respect of residential requirements. In 1972, the West Bengal State Government made several declarations that preferences would be accorded to local persons in lower level jobs whose mother tongue was Bengali or who had been domiciled in the State for the last ten to fifteen years. But the same government delayed in its implementation. On the other hand, the Maharashtra Government followed it more sincerely. In 1968, it issued a circular directing large business and government offices to hire local labour. ${ }^{21}$

\footnotetext{
${ }^{20}$ Ibid., p.46.

${ }^{21}$ T. K. Oommen, Citizenship, Nationality and Ethnicity (Cambridge: Polity Press, 1997), pp.145-48.
} 
Article 15(4) is to enable the State to make any special provision for the advancement of any socially and educationally backward classes of citizens or for Scheduled Castes and Scheduled Tribes. The State can act on the advice of the Backward Class Commission, under Article 340 of the Indian Constitution. Under Article 16(4) the State can make any provision for the reservation of appointments or posts in favour of any backward class of citizens which is not adequately represented in the services under the State. Two conditions are necessary to attract this provision: socially and educationally backwardness of citizens and inadequate representation in the services under the State.

\section{Threats from Within}

Despite achieving many merits in the sphere of governance, the pervasive virus of Hindutva (generally understood as anti-Muslim sentiments) has infected a large number of institutions and people in general. This threat of communalism resulted in the denial of justice to minorities particularly in the domain of the Fundamental Rights of the Indian Constitution. There are some facts which need to be placed in a proper context. The Hindu community is not the only one in the country who is conscious of its religion and traditions. Seven other minorities are also conscious of their religions. Difference lies at the point where the one happens to dominate over the resources of power and development. This religious consciousness seems to occupy pace in the minds of majority of the elected leaders, bureaucrats, police and security personnel and other sectors engaged in State-building, service delivery system, etc. It is a matter of chance that the dominant community happens to belong to the majority Hindu community. If people's religious consciousness remains a centrepoint of identity and bargaining within the sociological and cultural matrix, then people can be called collectively as community in the 
context of debating communalism in India. When this collectivity or the dominant part of it attempts or acts beyond this matrix and enters into the domain of politics and administration for its own construction, then the community representing the people can be reasonably labeled as followers of communalism.

Riots (basically anti-Muslim violences), in which several actors play roles before and after the crimes against humanity, poison many minds beyond boundaries of the rule of law. The term 'riot' is quite commonly used to state the matter related to all kinds of violence that take place at the inter-community level. For example, the recent violence in Gujarat has been termed by many, who visited the affected sites, as 'genocide' and 'state-sponsored crime against the Muslims' and not ordinary riots. However, it is a fact that communal riots have become unavoidable and uncontrollable menace in the country in which the members of the Muslim minority, in almost all parts of the country, become the victims of organized crimes. In all the largest communal riots since independence, state governments, ruled by several political parties, have delayed in controlling the situation for weeks. In most of these riots, minorities have suffered disproportionately.

The Sangh (a coalition of rightist forces to actualize majority religious supremacy and tradition in Indian polity and society) movement has been active to describe the Muslims minority in the country in such a manner as they are dangerous and undesirable community who do not qualify for being equal citizens. The Sangh (known for the group of anti-Muslim, antiChristian rightist-militant Hindu organizations) literatures and their speeches throughout the country during the Ram Mandir (Lord Ram Temple) movement and on other occasions clearly showed their prejudices against the Muslims minority. The Sangh movement has succeeded in widening its base even in the remote corners of the country together with their educational, cultural and 
institutional settings. Majoritarian consciousness is also reflected even in the government managed schools, history books, greetings and in cultural programmes. It is important to note that all successive governmental authorities ranging from districts to the Union/Federal Government have failed to even check the Sangh activities.

There are other areas--such as judiciary, media, education including the training institute for the top ranking civil services are not immune from this consciousness. As a result, the debate on the prejudices and discrimination against minorities in the country cannot be ruled out. Communal consciousness has become a threat because it has acquired time and space in the systems of power structure. This trend seems to go upward as there is neither any counter-strategy nor any alternative offered by the leaders and reformers owning the project of secularism. This project was used in words but never defined and enforced in rural and urban sectors. Even the ruling elite lacked commitment to secularism. Rightist forces were criticized, condemned and abused in such words like fascist, communal, and poisonous but the advocates of the project of secularism hardly worked to either promote secularism or to resist such forces. People at large failed to witness this project either in theory or practice and so the vacant space was gradually filled by those forces which had a complete blueprint of reconstructing the identity of the majority community and the nation. They took over the project of nation-state to create and reinforce a king of the state which was to address to the needs of majoritarian state and cultural nationalism.

As a result, the basic purpose of introducing and maintaining many infrastructures of democracy, justice and equality has failed to justify its cause vis-à-vis the Muslim minority. Voting rights are not all about democracy. Voting equality does not bring 'substantive' equality. It is basically the nature of the 
constitution and development of political culture which determine judicious distribution of powers, rights and privileges among different sections of multicultural society. Wherever these fundamental efforts have not been done, democracy has only served the purpose of 'absolute majority' against 'concurrent majority', or majority against minorities, or few against many.

\section{The Turkish Case}

It is generally believed and argued that the systems of governance in most of the countries are inspired by the notion of nation-state for long-term benefits within as well as outside their jurisdiction. First of all, the conceptual reality of nation-state provides two major safeguards to the governing institutions within the realm of national law and international law. At the domestic level, a nation-state seeks to presume its role as one of non-abiding indestructible source of power against the choice and will of minority community, which might claim the right to be different. As a result, a nation-state seems to define its own role and priorities vis-à-vis those constitutive elements, which differ from the homogenization project of the polity. At the international level, the 'absolute' sense of State sovereignty of a nation-state seeks to resist any pressure from the forces possessing higher military power and having greater shares in the globalization of world economy.

What has challenged the notional supremacy of a nationstate is the democratic ethos of governance in multicultural and plural nation-states where democracy, federalism, human rights, rights of minorities, fundamental rights and freedom of expression transformed political landscape. More democratization advocated tolerance on the part of the State. Federalism necessitated the acceptance of certain conditions on the part of the 
national/Federal Government towards the demand of nonmajorities. The culture of human rights opened the doors for national and international bodies to interfere into the sacred domain of the Nation-state. Fundamental rights of the individuals sought all reasonable rights from the State to raise questions on the policies and actions of the ruling institutions.

Therefore, a nation-state is perceived as a noncompromising sovereign agency vis-à-vis asymmetrical demands of the people. This has raised many internal conflicts in many parts of the world. There are many cases of rebellions, disagreements and categorical differences between a nation-state and its political constituents and between the majority and minorities. The operational scope of a nation-state is so limited that it fails to reach out to the inspirations of the disenchanted section of society. And many times, their demands also go beyond the national tolerance of acceptability. However, there are some examples in the world, which can show the survival of a Nation-state within the walls of diversities and differences. The key to success has been the principle of recognizing the needs of others, which can reasonably be attended by the State. In other words, a Nation-state is in a new phase of facing an acid test-whether to recognize the needs of the vulnerable communities and minorities as legal and political rights or not. Can a nation-state guarantee the right of identity maintenance or the like?

In reality, it would be difficult for a Nation or MultiNations-States to act as an absolute nation-state. Over centuries and decades, patterns of governance and legitimacy have changed. In the beginning, human beings defied kingship in many parts of the world. Later, they challenged feudalism and totalitarianism. Now, they are in the phase of challenging Statism. Such changes have witnessed violent, peaceful and evolutionary trends. Some Nation-states have volunteered their efforts to reach out to the 
aspirations of minorities and vulnerable groups and some have adopted such measures due to internal and external pressures. On the contrary, a Nation-state has today become vulnerable to the an individual country monopolizing world's 30 percent GDP and weapons of mass destruction, the United States and an umbrella organization, the European Union, which have been interfering into the sovereign domain of Nation-states on several pretexts since the fall of the Berlin Wall in 1989. Earlier, each communist and capitalist blocs have had the history of acting against several Nation-states. Therefore, a Nation-state, at present, is under tremendous pressure from both the domestic and external fronts.

\section{Imagined Homogenization}

Although a nation-state primarily seeks to achieve homogenization in order to create a national pattern of unity and understanding, yet it has been a very difficult process so far even in European part of the world. There are some examples, which can show certain social realities existing within Nation States. Charles Tilly has maintained that the European State-making turned towards homogenization at cultural, educational and linguistic levels through deliberate attempts. Eric Hobsbawm saw the merger of the State, Nation and Society to stand as a representative of an entire society or people. Earlier, it was believed that nationalism could not be a productive factor in plural societies. Nationalism was productive for democratic system. Ethnic and cultural homogeneity could produce a strong and viable democratic state mainly because of co-habitation and coterminality factors. However, it is a fact that Nation-states also carry over some contradictions.

The French Revolution vested the source of all sovereignty with the State. There are Alastions, Basques, Bretons, Catalons, 
Corsicans, Flemings and Occitanians nationalities who were forcibly integrated into France whose linguistic and cultural aspirations are considered detrimental to French Nation-state. Similarly, many Muslim citizens of France (originated from North Africa) feel discriminated by the French State on the basis of religious consideration of identity. Before World War II, the German Nation-state, particularly during the Hitler's leadership, pursued racist policies against the Jews along with many discriminatory laws on the pretext of the 'purity of blood.' Later, Germans adopted federal Constitution, which in itself contradicts a Nation-state. But its governmental attitude and policies against about three million Turks (citizens/migrant labourers) mirror discrimination allegedly sponsored by the State. Turkey is taken as the case for a Nation-state in Middle East. Some Authors like Frank Chalk, Kurt Jonasson, Werner J. Cahnman, Bernard Lewis and Uriel Heyd and to some extent T. K. Oommen ${ }^{22}$ have taken up the Armenian case as it has been raised by the Armenian lobbies in many European countries. Their remarks on Turkish Nation-state with reference to the Armenian genocide are unfortunately questionable.

Discourse on nation-state is generally attributed to the forces of modernity aimed at integration of nation with state. A nation-state is, therefore, the state of and for one/and/the nation. Nationalism is supposed to unite strange elements and to create a new form of social integration (the nation) and political solidarity (in the form of state) When we talk about nation-building in terms of modernity, it may be understood as 'political project' of building political institutions based on consensus, agreements and accommodation. With the consideration of the nation as one of its constitutive elements, the state seeks the role of an institution to

22 Nicole Topperwien, Nation-state and Normative Diversity (Bale, Geneve, Munich: Institut Du Federalisme Fribourg Suisse and Helbing \& Lichtenhahn, 2001), pp. 9-58. 
facilitate unity and integration. This strategy of state-driven integration, which is generally attributed to the process of modernity, witnessed strong protests in support of emphasizing 'the culture of difference' in terms of post-modernism. Counterreaction to the philosophical-cum-real project of nation-state stressed upon recognizing the demands in pursuit of difference. ${ }^{23}$

The creation of Turkish Republic by the Kemalist Revolution was based on the rejection of the history of the people as it happened in case of France. On the contrary, Indian national movement carried over the heritage of various ages including the institutions created by the British rulers. However, in the case of Turkey, the state came with a new project of nation-state, modernity and military elite-guided polity. The Turkish ruling elite headed by Ataturk wanted to act as Plato's Philosopher-King and his army as Platonic system for adequate defense. In reality, they were completely different from what Plato had desired for. After the recovery of the occupied territories of Anatolia and Rumeila, the restoration process began with the transplantation process. All methods were used to suppress the opposition (communist and religious leaders, institutions, legal codes, dress code and even greetings) as enemies off the new nation. Thus Turkey cautiously moved towards the phase of state consolidation programme in which the overarching image of the state and its armed wing were projected as protectors and nation-builders.

Ataturk considered dictatorship as a necessary evil for enabling people to govern themselves. He was also not in favour of liberal democracy. ${ }^{24}$ He created a new frame for a new picture of the Turkish State in which every day was to be altered. In this

23 Hanns Froembgen, Kemal Ataturk: A Biograpby (Karachi: Indus Publications, 1980, first published in 1928), p. 228.

24 Arshi Khan, "Turkish Perspective on Nation-state", The Pioneer (New Delhi), 19 July 2001, Op-ed. Page. 
pursuit, the Tribunals of Independence and restrictive measures were taken. To him, modern life on the European pattern was relevant and civilized. So he decided for the West with all institutional and moral mechanisms to indoctrinate European feelings among the Turks as their own new souls. In pursuit of these objectives, Ataturk went ahead with sweeping changes in the country. He looked at Europe as the only model and source of inspiration for Turkey. It was a very big decision for the whole people who given the opportunity for pick and choose could have directly rejected this option. The issue in Turkey was to end the temporary occupation of the foreign forces. Turkey was slowly moving towards modernization after Tanzimat and after the annihilation of Janissaries in 1826.

The modernization process was mainly in the sphere of the some of the state agencies, defense, press and education and in the houses of elite section. The sudden shift took place after 1923 when the state directly came in conflict with the people. For example, to Ataturk, the chief root of evil was the Turkish alphabet which was replaced by the Latin script. The Arabic language was prohibited for religious use. First monuments, statues and buildings were the works of foreign artists. So the art, literature, music, theatre, etc. The Kurdish people had to submit to the process of nationalization. Then the government proceeded against the Communists and the Dervish Order of Nakshbandi. The Turkish nation-state sacrificed more than half its income for the maintenance of the Forces. As a result, identity of state was given primacy over the identity of people in which we find today the issue of secularism, Kurdish issue and the role of the army.

The democratization process began since 1950 but the attempts of political parties to differ with the established political norms were never approved by the Turkish armed forces which is the self-proclaimed guardian of the country. Despite the 
stronghold off the armed forces over the civilian authority, Turkish democrats in the formation of different political parties have continued to pursue their activities in elections and the formation of the governments including coalition and minority governments. What has happened new in Turkey over the years that democratic experiments made its way into the domestic politics challenging the hold of the old elite and the guardians. This resulted in the interventions of the armed forces taking over the civilian government on the pretext of protecting the constitution. Such interventions in 1960, 1971, 1980, 1996 and continuing threats to the civilian government further strengthened the determination of the Turks for more democratization.

On the other hand, Turkey needs to go beyond Ataturkism if it is destined to play a role larger than its size. The Turkish nation-state is not fully acceptable to the European Union which has been quite open in its support to the Kurds. After 1980, three million Turkish people in Germany are further divided into Turks and Kurds. The nature and scope of the Turkish democracy has changed over the years mainly due to the emerging party system and the political culture in the country. The Turkish foreign policy, its relations with others, its participation in many Western institutions and its desire for the EU membership would necessitate the larger role of political parties as legitimate representative of people.

Europe has changed a lot after 1945. It encompasses federal, regional and nation-states. German and France are no more models but as power brokers in the EU. Belgium, Switzerlan, South Tyrol, Aaland Island are examples in the area of subnational and territorial autonomy arrangements. Similarly there are many examples of freedom of religion, practices and institutions in the Western world which can be good lessons for Turkey. Turkey has to look into this fact. On the contrary, Turkish armed forces 
have been engaged in three major practices: military take-over of the civilian administration, closure of political parties and constantly building pressures, restrictions and monitoring over the civilian government. This seems to be undemocratic and antiEuropean today.

The election of the highly prejudiced like leader like Sarkozy in France in mid 2007 has neither worried the French army nor the European secularists. In his first inaugural speech, he spoke mainly against Turkey. France is also known for opposing Turkey in the EU membership campaign and condemning Turkey on the Armenian issue. Most of the Western countries have been electing pro-Evangelist political leaders. However, in the case of Turkey, the so-called Islamists are basically democrats who are not prejudiced like Evangelists or Sarkozy. The Turkish armed force generals must take lessons from the European counterparts who are promoting unity in diversity. It would be undemocratic to deny due rights and respect to the legitimate leaders in Turkey who are quite moderate and temperate in comparison to their Western counterparts.

Political parties are generally considered as the fundamental wheels of a chariot in which political structures and processes make journey towards strengthening the very basis of democracy and popular sovereignty and reconsidering post-modern realities. In the other words, political parties have become like the lifesaving remedy for democratic participatory and inclusive democracy. In most of the societies, political parties have also operated as a movement and protest against colonialism, occupation and authoritarianism. They continue to play a vital role in post-colonial era. It would not be inappropriate to say that political parties have acquired more important role in all modern states where many disputes of settlements and controversies continue to exist between state and society, on the one hand and 
between dominant and dominated sections of a society, on the other.

But modern democracies have not yet compromised with the emerging demands for parity between privileged and disadvantaged sections, securing minority rights and regional autonomy and bridging gap between masses and governing elite. In other words, many democracies still face the problem of the continuation of the domination of few over many. In this context, both political and moral obligations of political parties have increased tremendously to provide reasonable space to all those sections in governance whose agenda for the need of accommodation and tolerance is to be understood in the perspective of the constructive approach to nation building.

\section{Endangering Democracy}

The Republic of Turkey, which holds a sound record of periodic elections and maintaining modern state system in the Middle East, has been facing many questions vis-à-vis the freedom and rights of political parties, human rights and inclusive democracy. Many questions to Turkish democracy seem to dominate the subject of the secularism, respect for religious values, minority rights and democracy itself. It is fact that the Turkish state has maintained the modern tradition of electoral campaigns, secret ballot box, periodic elections and parliamentary sessions. However, it is also important to recall that the country has passed through several stages of tests and controversies in which military interventions $(1960,1971,1980)$, military pressures and influence over civilian governments, closure of political parties and several hard provisions in the Turkish constitution of 1982, certainly question the legitimacy of Turkish democracy. 


\section{Closure of the Virtue party and Politics of Exclusion}

Many questions are now being raised over the compatibility of the Turkish State with the western liberal tradition of governance. ${ }^{25}$ Certain doubts created over the weakening of the democratic principles are likely to be mentioned as realities in the history of Turkish politics. Most unfortunate decision of the Constitutional Court on closing the main opposition party and the third largest party in the Turkish Grand National Assembly (parliament) --- Virtue Party, has certainly damaged the image of Turkish democracy. The Constitutional Court which conducted the closure case for more than a year, decided on June 22, 2001 to ban it on charges of being a center of Islamic fundamentalism. The Court also said to topple two Parliamentarians - Ms. Nazli Ilicak and Mr. Bekir Sobaci. The Court also decided to ban five parliamentarians - Ms. Ilicak, Ms. Merve Safa Kavakci, Bekir Sobaci, Ramadan Yenidede, and Mehmet Silay from political life for five years on charges of causing the ban of the party with their announcements and moves. This has been widely described as a political move made under certain compulsive factors. The closure decision and related developments have resulted in a denial of democracy. ${ }^{26}$ Earlier, about 36 political parties were banned. The Virtue became the victim due to its own composition rather than its agenda, party's policies and election manifesto. Throughout its existence, the party made no efforts to give any excuse to anyone for justifying the cause of the perceived threat of closure. In fact its composition (which included non-westernized and pro-Islam Turks but neither obscurantist nor extremist) made it vulnerable to the statists. This can be better understood by analyzing their

25 Arshi Khan, "Military versus Secular in Turkey", The Telegraph (Calcutta, India), 27 July 2001, edit page.

${ }^{26}$ See the Turkish DailyNews (Ankara), June 22 to July 15, 2001, domestic coverage and opinion column. 
demands and issues raised in electoral campaigns. This verdict deprived 102 out of total 550 Deputies of their democratically achieved fundamental rights of representation in Turkish parliament.

The Virtue Party described the decision of closure against democracy while many others expressed anger and sorrow in subdued tone. Its reformist leader Mr. Abdullah Gul called it a political ruling. He said, that with this verdict the boundaries of democracy in Turkey were further narrowed. This verdict would create problems for Turkey in the international arena. How would Turkey explain to the world that because of statements of two members, the party was banned. In the opinion of Mr. Ilnur Cevik, the editor of Turkish Daily News, the ban was a blow to Turkey's fragile democratic system and those two banned had nothing to do with fundamentalism. Another columnist, Mr. M.A. Birand said that it added another blow to its own already bruised democratic system. Soon after the ban, the Swedish Ambassador to Turkey, Mr. Henrik Liljegren called it 'unfortunate'. Later the German Minister of Justice, Hertha Daeubler said: "with due respect, this raises some concerns among the Germans and the European public." 27

\section{Kurdish Question}

On the Kurdish issue, Turkey is stepping up some reforms. Turkey lived through the debate of "freedoms versus security" between 1984 and 1999 and paid a heavy price. Neither violence nor force used against it produced a sustainable solution to the problem, and eventually a new era began. The policy of

${ }^{27}$ Dogu Ergil wrote in the Turkish DailyNews (Ankara), 12 December 2005. 
approaching the Kurdish problem from a peaceful stance, developing since 1999, should thus be strengthened, not weakened. Today's Turkey is no longer a country where the "use of force" is a viable option in political, social, economic and even military terms. We have no other option but to resort to constructive policies. Prime Minister Recep Tayyip Erdogan tried to begin a new era in the Southeast since June 2005. He gave the impression that the government could negotiate with the PKK on a political platform. Despite the promises of reforms, development and negotiation, the government has failed to initiate any measures to address the "Kurdish reality". The lack of policies created a gap of authority. The civilian and military forces in the region took independent and sometimes contradictory stances. Other Kurdish political figures in Turkey, like Perafettin Elçi and Ýbrahim Güçlü, defend federalism. ${ }^{28}$

Veteran journalist Mr. Kinzer ${ }^{29}$ was surprised by the absence of soldiers or armored vehicles anywhere on the streets in Diyarbakir. Police officers keep out of sight. Most important, people now say whatever they please. He found a selection of books with titles like 'History of Kurdistan' and 'Turkey's Kurdish Problem.' No such books could possibly have been sold here during the 1990s, when the very word 'Kurdistan' was taboo and the term 'Kurdish problem' was taken to refer to an illegal form of separatism." People feel free to say many things as they are no longer afraid to speak out. A Kurdish writer told Stephen Kinzer at a book fair that the government was insisting that there were no Kurds, that there was no Kurdish language or culture. They arrested us and closed our organizations. Now, so much has changed, especially in the last few months. Our problems haven't

28 Stephen Kinzer, "Kurds in Turkey: The Big Change," The New York Review of Books, Volume 53, No. 1, from Jan. 12. 2006.

${ }^{29}$ Ibid. 
been solved, not at all, but at least we can talk about them honestly. It's a huge difference."

Kinzer witnessed years of terrorist warfare that was waged in these lands and was further surprised to see a large banner advertising a conference that was being held. The subject was "The European Union Accession Process and the Kurdish Problem." When he walked into the packed hall, a local politician was delivering a passionate harangue. "For so many years, the Turkish state called us criminals, saying that it was not possible to have dialogue with us and that we had to be crushed," he told the rapt crowd. "This is the repeated tragedy that created the Kurdish problem. The only reason Kurds were forced to begin the armed struggle was the way the Turkish state has treated Kurds at every stage in the history of this country." These would have been highly dangerous words a couple of years ago. Even now, police agents monitor and videotape similar conferences. However, their presence did nothing to intimidate the speakers in Diyarbakir. "They watch us just like before, but they can't do anything to us anymore," one man told me. "This is a democracy now. We're becoming European. The state can't touch us." ${ }^{10}$

This means increasing and improving its legal, political and economic standards and treating its Kurdish regions in line with standards that are generally referred to as "European." In the last few years, the Turkish state has granted many rights to the Kurds in lieu of upgrading its legal and political standards to fit that of the European Union. These were found to be too late and too little by Kurds but dangerously generous by many Turks that favored the status quo. The legalized Kurdish-language television broadcasting is still very limited. Private schools are allowed to offer classes in Kurdish, but most Kurds can only afford to send

${ }^{30}$ Northern Iraq raid wins vote, Turkish Daily News, 19 October 2007. 
their children to public schools. Kurdish is not a language of curriculum in these schools, nor is it in the universities. It may never be. But when in August 2005, Prime Minister Recep Tayyip Erdogan delivered a speech in Diyarbakir and promised to "resolve every issue with more democracy" and added that "the Kurdish issue does not belong to a part of our nation [only to the Kurds] ... We accept it as real and are ready to face it ..." thereby distinguishing the security problem from the "Kurdish" one and associating the latter with democracy, he impressed the Kurds but infuriated the nationalists and a greater part of the bureaucratic establishment. Mr. Kinzer has also picked up the general feeling that Kurds in southeastern Turkey have a boundless, almost childlike hope that the EU will lead them out of their situation. They believe in the transforming power of the EU. The mere prospect of joining the EU has already changed Turkey. What actual membership could do -- and whether it will ever materialize -- remains tantalizingly uncertain.

The conditions that existed between 1984-1988 have changed. The situation has gone beyond being a simple PKK terror problem. We have come to the point where the problems in the Southeast will not be solved by the food-work formula, in other words, by investment alone. Taking economic and social precautions in the region, along with a few cultural steps for show purposes, will not do the trick. The "Kurdish problem" has turned into an identity problem and, at the same time, a political problem. Had we taken a few steps in the six months following the ceasefire announced by Ocalan in 1999, we might have gotten ahead of where we are now. But the political leaders in power at the time did not listen to the warnings of the military. They made no moves in terms of policy.

Now the situation is completely different in southeastern Turkey which is faced with New Iraq in The New Middle East. 
Iraq is practically divided into three semi-independent states controlled the Kurds, Shiites and the both in north, south and the centre. This partition plan was put into effect by the Americans and the British since 1991 and was finally realized after the invasion of Iraq in 2003. They used northern Iraq as the main zone of their intelligence and anti-Iraqi activities since 1991. As a result, majority of Kurds see northern territory as Kurdish country which would certainly encourage anti-Turkish activities among the Kurds of Turkey. Safe-haven provided and protected by the US to the Kurds in northern Iraq proved not only anti-national and divisive strategy against the sovereign rights of Iraq but it also threatened Turkish sovereignty.

In October 2007, Kurdish terrorist attacks resulted in the death of at least 15 Turkish soldiers and 20 civilians. After Ankara passed a strong resolution in Parliament for incursions into northern Iraq, both the US and Europe asked Turkey to restrain from military actions against the Kurds while Syria supported Turkey. There were 507 votes cast in favor of the motion and 19 against (pro-Kurdish Democratic Society Party, known as DTP). ${ }^{31}$ Ankara says NATO allies have not done enough to help Turkey deal with members of the outlawed Kurdistan Workers' Party (PKK) following a series of deadly cross-border attacks against Turkish troops. ${ }^{32}$ The US which is known for destroying Iraqi State and Society, also warned Turkey against incursions. Lt. Gen. Carter Ham, Director of operations at the Joint Chiefs of Staff, told a briefing at the Pentagon on October 16: "Iraq is a sovereign nation and obviously they, you know, would take their sovereignty

${ }_{31}$ NATO urges restraint over Iraq incursion, Turkish Daily News, 19 October 2007.

32 Umit Enginsoy, "US toughens rhetoric", Turkish Daily News, 19 October 2007. 
in defense of their territory quite seriously," ${ }^{133}$ George Bush said at a White House press conference: "We are making it very clear to Turkey that we don't think it is in their interests to send troops into Iraq." 34

In fact, the Turkish democracy experimented with the two major political forces such as the Republican People's Party as Kamalist mouthpiece and Turkish liberals represented by the 'Reformed Republicans' like the Motherland Party, the True Path Party, National Action Party, etc in the first phase of democratization. Later the 'third force' emerged as a strong political force in the name of the national Salvation Party, Virtue Party, etc which basically integrated and mobilized masses on vital domestic issues such as inflation, employment, health, education, etc along with their emphasis on close relations with the European union. This force is less Kamalist and more democratic, less elite and more public, less authoritarian and more negotiable and deliberative and accessible. In other words, their emphasis is not so much on secularism but on democracy in which they see the future of the Republic. However, it does not mean that they are opposed to secularism. Their difference with Kamalist secularism is mainly on one point, i.e., giving religious freedom to the people as universal fundamental and human right to the extent of its acceptability in any democracy. Such efforts can be seen a very healthy trend in Turkish polity and society in which identities and their cultural freedoms should no longer be held hostage to any kind of polity.

33 Bush urges Turkey not to strike Iraq, Turkish Daily News, 19 October 2007.

${ }^{34}$ C. H. Dodd, "Ataturk and Political Parties", in Metin Heper and Jacob M. Landau, eds., Political Parties and Democracy in Turkey (London, New York: I.B.Tauris \& Co Ltd, 1991), p.33. 
In fact, one can find reason in the policy of this political force which can be catalyst in defusing the emerging crisis between the hardcore Republicanism and Democratism. There must not be suspicion and hostility between society or a part of it and the State. The third force is creating a negotiating space between the two for seeking peace, democracy and stability in a delicate environment of 'imagined threats'. Finally it could be understood in the context of the failure of Europe as the only civilization and the delaying process of denying the EU membership to Turkey. It also seems that Germany and France were the models before Ataturk in terms of modernity and nation-state. Both the models are not universal as they have not been followed by even their neighbours like Switzerland, Belgium, Italy, Spain and the Scandinavian. An ethnic German can be both national and citizen. This is not thinkable in the case of a non-ethnic German. Similarly, minority and its rights have not been recognized by France. So it is important to rethink over the Turkish social reality and corresponding concessions.

The Turkish generals need to rethink over the views of Ataturk who had thought of the role of a political party as inclusive of the interests of all Turks. He was always ready to listen to an ordinary Turk provided he was a patriotic citizen. Patriotism, not nationalism was his guide. ${ }^{35}$ Ataturk had declared that the new Turkish state is a people's state, the state of the people, asking them for their views on governmental policies in informal ways. It is the interests of all the people that are paramount in his thinking. ${ }^{36}$ However, there are indications of positive changes on the part of the armed forces. Turkish people approved the historic referendum on 12 September 2010 on the amendment of 26 Articles of the 1982 Constitution. Turkish democracy is getting characterized by increasing civilian control over military. The ruling party is appearing more confident in pursuing various

35 Ibid. 
internal reforms under the European pressures for a shift from tutelage to deliberative democracy. On the other hand, the main opposition party- $\mathrm{CHP}$ is also showing its choice for democratic polity free from military interferences. Contemporary Turkish politics seems to be centered at preparing itself both economically and politically for seeking the membership of the European Union without conventional delaying excuses.

\section{Conclusion}

Both India and Turkey are democracies with a difference. The former has adopted the federal model to achieve the goals of democracy through the means of symmetrical and asymmetrical federalism, differentiated rights, common citizenship, depoliticizing of the armed forces, and the policies for the weaker sections of the society. Despite this, there are the problems of human rights in many parts of the country along with the existence of exclusion based on communal considerations. There are pressures from many sides. National political parties have succeeded in breaking the stronghold of the dominant Congress party in the country. On the other hand, regional political parties have challenged the centralizing tendencies of the Federal Government. However, such efforts have neither checked corruption nor communalism in the country. In fact, many federal attributes remain suspended due to the problem of operational realities. The case of the Muslim minority is quite transparent. The State has accepted their identity rights but refused any safeguards in the case of exclusion. Therefore, rights in the absence of their use or utility become only symbolic rights. On the issue of the Jammu and Kashmir, the Federal Government maintains policies different from what it pursues for the problem in the North-East. We have not gone beyond blaming our next-door neighbour without looking into the involvement of other forces. We have not 
yet decided for a 'change' in our policies towards Kashmir. India needs to facilitate the process of dialogue, interaction and concessions for democratic unity. We need to minimize our military means in order to promote democratic goals.

Similarly, Turkey has adopted the ideology of nation-state with strict adherence to Kemalism/Ataturkism through the terrains of modernity, common citizenship, Kamalist secularism along with the heavy backing of the armed forces. Political engagement of army over decades seems to be detrimental to the health of democracy. There is no doubt that the country has achieved a lot in industrialization, foreign trade, health, constructions, food processing technology, tourism and defense sectors but it seems to be failing in adequate response to the issue of identity and democratization process which also involve the management of Southeastern Turkey, electoral reforms, reduction in the tenure of the elected president, reforms in the National Security Council, and more freedom of religion and press.

Changes in Turkey are inevitable due to the dynamics of this sensible world. The Turkish 'periphery' has come to centrestage vis-à-vis the Turkish elite. They have their own demands, needs, choices and expectations. Only reversal of the democratization process can isolate the 'periphery' consisting the majority of the country. Turkey is moving towards democracy. Strict adherence to Kemalism would theoretically discourage oppositions, disagreements and dissents against the set agenda of 1920s and 1930s. Dominance of military and bureaucracy over the civilian government is anti-democratic feature of participatory politics. It is quite normal to face divergent trends at certain stages as it happened in the case of other democracies. It is not to fear but to face challenges. It is not to doubt its people but to understand them. 
Since 1950, Turkey experimented with different waves of democracy and military interventions, warnings, monitoring and supervisions. Earlier the Kemalists (European centric) dominated the political space of Turkey, that too before 1950. Later, democratic parties emerged as competing force in the country. This second wave emerged when Turkey became an American ally in Cold War politics. Turkish dominant parties also developed close associations with the United States. It was under the leadership Bulent Ecevit and others, Turkey made momentary switch-over to the socialist and Islamic blocs in order to expand its wings other than the West.

After the Kemalists and liberal political parties, politics of the 'periphery' came to the centre-stage which was dominated by the middle and lower middle class. Political awakening of the rural areas, small businessmen, and the middle class expressed their dissatisfaction with both the Kemalists and the liberals who could neither achieve the European membership nor could provide safeguards majority of Turks from the effects of globalization. The 'periphery' occupied the 'axis' through the Welfare party, the Virtue party and the Justice and Development party. It would be wrong both in theory and practice to call them Islamists as they have never endorsed such programmes. They have always expressed commitments to the West.

On the issue of scarf, they have not objected to its use who wants to it as part of their culture, tradition and belief. Nor they have said to use scarf. They have left it to the choice and will of the people. On the Kurdish issue, they have preferred negotiable means for settlement. They have reconciled with the West on the question of Cyprus without any 'substantive return'. They have adhered to the EU level reforms and electoral campaigns. They have been persuading for the EU membership. They have been toughest against terrorism. Therefore, they can be better called as a 
third wave or third force in contemporary Turkish politics, representing popular sovereignty.

Today Turkey needs to be united internally in order to face difficulties around its borders. Divided Cyprus has engaged the EU which is more in favour of Greece and Southern Cyprus. The NATO will be more in favour of Armenia and the former communists of Europe than siding with Turkey in future. The eastern border of Turkey is now faced with new enemies and neighbours whose political identity is more sponsored and engineered by the foreign forces. Changes in Iraq and mounting pressures on Syria and Iran would be damaging for Turkey in future. Therefore, the issue in Turkey is creating more channels for seeking unity and solidarity within. Turkey can take lessons how nation-states are shifting from modernity to post-modernity. It can take lessons from India where history is the source of unity and social strength. The policy of the rejection of the self and history and the imposition of the alien culture is not a viable and sustainable recipe for democracy, unity, peace, security and development. 